\title{
ANALISIS LAPORAN KEUANGAN
}

Makalah ini disusun untuk memenuhi tugas

Pada mata kuliah kewirausahaan

Dosen pengampuh : Dra. Hj. Nuraeni Gani, MM

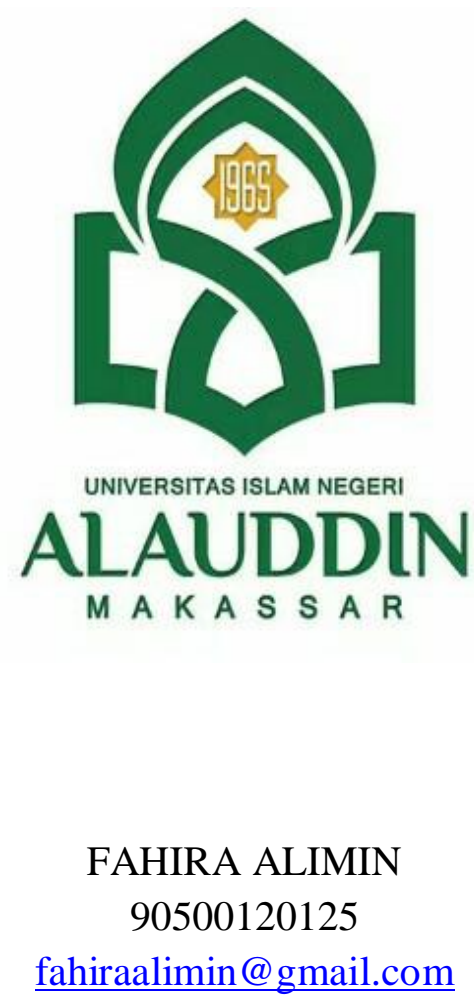

PRODI PERBANKAN SYARIAH

FAKULTAS EKONOMI DAN BISNIS ISLAM

UNIVERSITAS ISLAM NEGERI ALAUDDIN MAKASSAR 


\section{KATA PENGANTAR}

Puji syukur kami ucapkan kehadirat Allah SWT atas segala rahmat-Nya sehingga makalah ini dapat tersusun sampai dengan selesai. Tidak lupa kami mengucapkan terima kasih terhadap bantuan dari pihak yang telah berkontribusi dengan memberikan sumbangan baik pikiran maupun materinya.

Penulis sangat berharap semoga makalah ini dapat menambah pengetahuan dan pengalaman bagi pembaca. Bahkan kami berharap lebih jauh lagi agar makalah ini bisa pembaca praktekkan dalam kehidupan sehari-hari.

Bagi kami sebagai penyusun merasa bahwa masih banyak kekurangan dalam penyusunan makalah ini karena keterbatasan pengetahuan dan pengalaman Kami. Untuk itu kami sangat mengharapkan kritik dan saran yang membangun dari pembaca demi kesempurnaan makalah in 


\section{DAFTAR ISI}

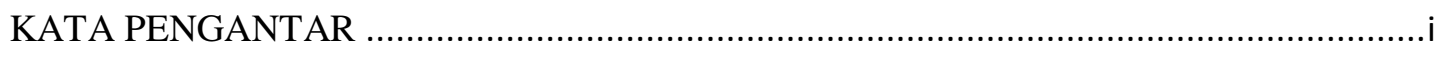

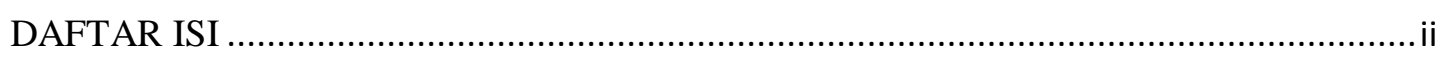

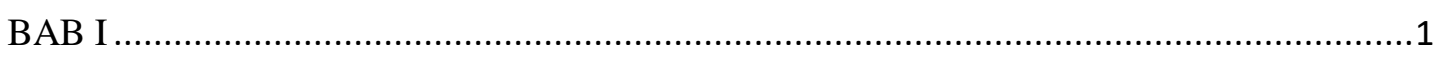

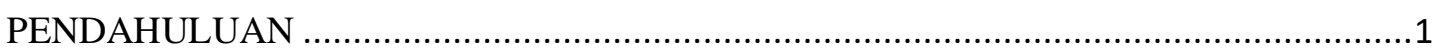

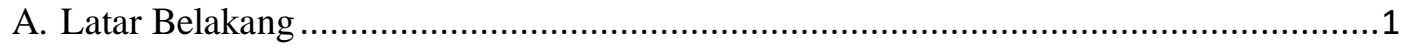

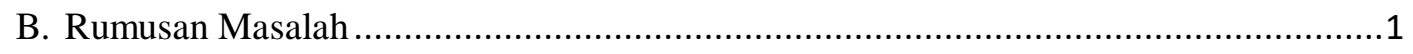

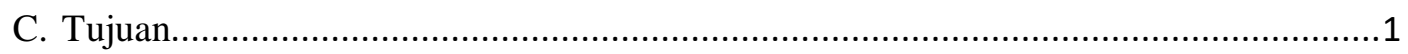

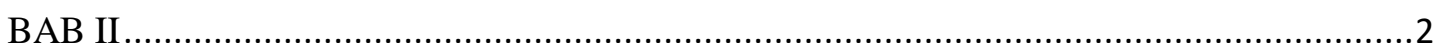

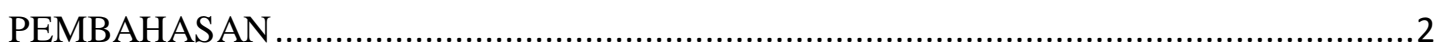

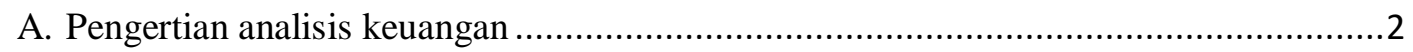

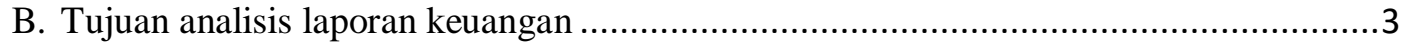

C. Macam - macam metode analisis keuangan ...........................................................

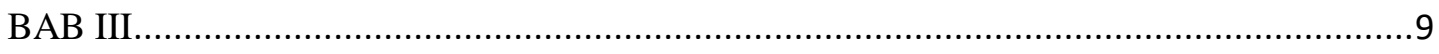

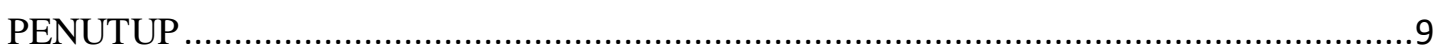

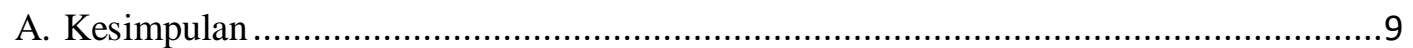

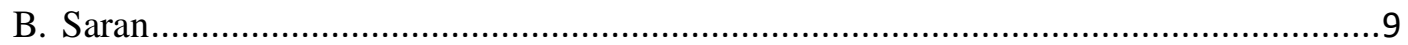

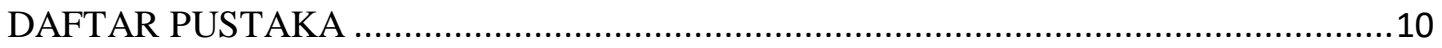




\section{BAB I}

\section{PENDAHULUAN}

\section{A. Latar Belakang}

Di masa globalisasi disaat ini, semakin banyak perusahaan- perusahaan yang berdiri di Indonesia. Baik perusahaan sejenis ataupun yang tidak sejenis. Tiap perusahaan tentu mempunyai rencana keuangan yang berbeda- beda. Dikala ini seluruh perusahaan harus membuat suatu laporan yang berkaitan dengan pertumbuhan keuangan perusahaan dalam suatu periode tertentu. Pihak- pihak yang mempunyai kepentingan terhadap pertumbuhan suatu perusahaan sangatlah perlu untuk mengenali keadaan keuangan suatu perusahaan.

Laporan keuangan ialah suatu media informasi yang digunakan oleh suatu perusahaan untuk memberi tahu kondisi serta posisi keuangan perusahaan kepada pihak- pihak yang berkepentingan ialah pihak internal serta eksternal perusahaan yang berguna untuk pihak tersebut dalam pengambilan keputusan secara ekonomi. Informasi tersebut disusun serta disajikan perusahaan dalam bentuk neraca, laporan laba- rugi, laporan pergantian modal serta laporan arus kas. Sebab laporan keuangan ialah bentuk pertanggung jawaban pimpinan perusahan ataupun pihak manajemen atas tugas yang diberikan untuk mengelola perusahaan kepada pihakpihak yang berkepentingan dalam perusahaan. Bila perusahaan tidak membuat laporan keuangan, maka pihak- pihak yang berkepentingan dalam perusahaan tidak bisa mengambil keputusan ekonomi dalam rangka memajukan perusahaan

\section{B. Rumusan Masalah}

1. Apa itu analisis keuangan?

2. Apa tujuan analisis laporan keuangan?

3. Apa saja macam - macam metode analisis laporan keuangan?

\section{Tujuan}

1. Dapat mengetahui pengertian dari analisis laporan keuangan.

2. Dapat mengetahui tujuan dari analisis laporan keuangan.

3. Dapat mengetahui macam-macam metode analisis laporan keuangan. 


\section{BAB II}

\section{PEMBAHASAN}

\section{A. Pengertian analisis keuangan}

Analisis laporan keuangan terdiri dari dua bagian kata, ialah" analisis" serta laporan keuangan". Analisis merupakan penguraian suatu permasalahan ataupun kasus dan menjelaskan mengenai hubungan antara bagian- bagian yang terdapat di dalamnya untuk selanjutnya diperoleh suatu penafsiran secara keseluruhan. Sebaliknya laporan keuangan merupakan suatu penyajian terstruktur dari posisi keuangan serta kinerja keuangan suatu entitas.

Harahap (2011:190) mengungkapkan analisis laporan keuangan berarti menguraikan pos-pos laporan keuangan menjadi unit informasi yang lebih kecil dan melihat hubungannya yang bersifat signifikan atau yang mempunyai makna antara satu dengan yang lain baik antara data kuantitatif maupun data nonkuantitatif dengan tujuan untuk mengetahui kondisi keuangan lebih dalam yang sangat penting dalam proses menghasilkan keputusan yang tepat.

Analisis laporan keuangan merupakan suatu proses penelitian laporan keuangan beserta unsur- unsurnya yang bertujuan untuk mengevaluasi dan memprediksi keadaan keuangan perusahaan atau badan usaha serta mengevaluasi hasil hasil yang sudah dicapai perusahaan ataupun badan usaha pada masa lalu serta saat ini.

Inti dari laporan keuangan merupakan menggambarkan pos- pos keuangan perusahaan yang diperoleh dalam suatu periode. Dalam perusahaan kita memahami beberapa macam laporan keuangan seperti:

a Neraca, ialah laporan yang menampilkan jumlah aktiva( harta), kewajiban( utang), danmodal perusahaan( ekuitas) perusahaan pada saat tertentu. Maksudnya dari suatu neraca akan tergambar berapa jumlah harta, kewajiban, serta modal suatu perusahaan.

b Laporan laba rugi, menunjukkan keadaan usaha suatu perusahaan dalam periode tertentu. Maksudnya, laporan laba rugi harus terbuat dalam suatu siklus operasi ataupun periode tertentu guna mengetahui jumlah perolehan 
pemasukan( penjualan) serta biaya yang sudah dikeluarkan, sehingga bisa diketahui, perusahaan dalam kondisi laba ataupun rugi.

c Laporan perubahan modal, ialah laporan yang menggambarkan jumlah modal yangdimiliki perusahaan dikala ini. Setelah itu laporan ini pula menampilkan perubahan modal serta sebab- sebab berubahnya modal

d Laporan catatan atas laporan, keuangan ialah laporan yang dibuat berkaitan denganlaporan keungan yang disajikan. Laporan ini membagikan informasi tentang penjelasan yang dianggap perlu atas laporan keuangan yang terdapat sehingga menjadi jelas karena penyebabnya. Tujuannya supaya pengguna laporan keuangan menjadi jelas akan data yang disajikan.

e Laporan arus kas, ialah laporan yang menunjukkan arus kas yang masuk serta arus kasyang keluar diperusahaan. Arus kas masuk berbentuk pendapatan ataupun pinjaman dari pihak lain. Ada pula arus kas keluar ialah biaya- biaya yang sudah dikeluarkan perusahaan. Baik aruskas masuk ataupun arus kas keluar dibuat untuk periode tertentu

\section{B. Tujuan analisis laporan keuangan}

Tujuan analisis laporan keuangan sendiri pada hakikatnya adalah untuk membantu pemakai dalam memperkirakan masa depan perusahaan dengan cara membandingkan, mengevaluasi, dan menganalisis kecenderungan dari berbagai aspek keuangan perusahaan (Wahyudiono, 2014: 11).

Analisis laporan Keuangan dilakukan untuk mencapai beberapa tujuan. Misalnya dapat digunakan sebagai alat screening awal dalam memilih alternatif investasi atau merger, sebagai alat forecasting mengenai kondisi dan kinerja keuangan di masa datang sebagai proses diagnosis terhadap masalah-masalah manajemen, operasi atau masalah lainnya, atau sebagai alat evaluasi terhadap manajemen (Darminto, 2011: 57). Dapat disimpulkan bahwa analisis laporan keuangan bertujuan untuk mengetahui kondisi keuangan yang ada agar dapat diketahui dampak yang dapat mempengaruhi keberadaan perusahaan maupun kinerja perusahaan nantiny 


\section{Macam - macam metode analisis keuangan}

1. Analisis Rasio

Analisis rasio merupakan metode analisa dengan menggunakan perhitunganperhitungan perbandinganatas data kuantitatif yang ditujukkan dalam neraca ataupun laba rugi. Pada dasarnya perhitungan rasio- rasio keungan ialah untuk memperhitungkan kinerja keuangan perusahaan di masa lalu, disaat ini, dan kemungkinannya di masa depan. Analisis rasio keuangan mempunyai tipe sebagai berikut:

- Rasio Likuiditas( liquidity ratios)

Merupakan gambaran yang menampilkan keahlian perusahaan untuk memenuhi kewajiban jangka pendek. Dalam rasio- rasio likuiditas, analisa bisa dilakukan dengan menggunakan rasio sebagai berikut:

a. Rasio Lancar( Current Ratio) Rasio lancar ialah rasio untuk mengukur keahlian perusahaan dalam membayar kewajiban jangka pendek ataupun utang yang segera jatuh tempo dengan aktiva lancar yang tersedia

\section{Aktiva Lancar

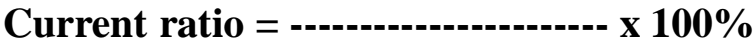

Hutang Lancar

b. Rasio Cepat (Quick Ratio atau Acid Test Ratio)Rasio cepat merupakan rasio yang menunjukkan kemampuan perusahaan dalam membayarkewajiban atau utang lancar dengan aktiva lancar tanpa memperhitungkan nilai persediaan.

\section{Aktiva Lancar -Persediaan

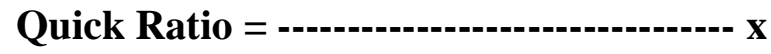

Hutang Lancar

- Rasio Aktivitas

Rasio aktivitas merupakan rasio yang digunakan untuk mengukur efisiensi efektivitas perusahaan dalam menggunakan aktiva yang dimilikinya.Dalam analisa aktivitas rasio yang digunakan adalah:

a. Rasio Perputaran Persediaan (Inventory turnover ratio)Rasio perputaran persediaan, mengukur aktivitas atau likuiditas dari persediaan perusahaan. 
Rumusnya :

\section{Harga Pokok Penjualan}

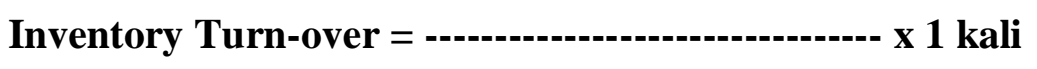

\section{Persediaan}

b. Rasio Perputaran Total Aktiva (Total Asset Turn Over Ratio)Perputaran total aktiva menunjukkan efisiensi dimana perusahaan menggunakan seluruhaktivanya untuk menghasilkan penjualan.

\section{Penjualan \\ Total Asset Turn-over = --------------------- $x 1$ kali}

- Rasio Sovabilitas

Rasio aktivitas ialah rasio yang digunakan untuk mengukur efisiensi/ efektivitas perusahaan dalam menggunakan aktiva yang dimilikinya. Rasio yang digunakan adalah:

a. Rasio Hutang Terhadap Aktiva( Total Debt to Asset Ratio)

Rasio ini mengukur seberapa besaraktiva industri dibiayai oleh utang ataupun seberapa besar hutang industri mempengaruhi terhadap pengelolaan aktiva. Rumusnya dibawah ini

\section{Total hutang}

Debt to assets ratio = ------------------- x 100\%

\section{Modal Aktiva}

b. Rasio Hutang Terhadap Ekuitas (Total Debt to Equity Ratio)Rasio ini menunjukkan hubungan antara jumlah utang jangka panjang dengan jumlah modal sendiri yang diberikan oleh pemilik perusahaan, untuk mengetahui jumlah dana yang disediakan kreditor dengan pemilik perusahaan.

\section{Total hutang}

Debt to equity ratio = ------------------ x 100\%

\section{Modal Sendiri}

- Rasio Profitabilitas 
Adalah kemampuan perusahaan mendapatkan laba melalui semua kemampuan, dan sumber yang ada seperti kegiatan penjualan, kas, modal, jumlah karyawan, jumlah cabang dansebagainya.

a. Margin Laba Kotor (Gross Profit Margin)Margin laba kotor adalah ukuran persentase dari setiap hasil sisa penjulan sesudah perusahaan membayar harga pokok penjualan.

Laba Kotor

Gross Profit Margin = -------------------- x 100\%

Penjualan

b. Margin Laba Operasi (Operating Profit Margin)

Margin laba operasi adalah ukuran persentase dari setiap hasil sisa penjualan sesudah semua biaya dan pengeluaran lain dikurangi

kecuali bunga dan pajak, atau laba bersih yang dihasilkan dari setiap rupiah penjualan.

\section{Laba setelah pajak \\ Operating Profit Margin = \\ Penjualan}

c. Margin Laba Bersih (Net Profit Margin)Margin laba bersih adalah ukuran persentase dari setiap hasil sisa penjualan sesudah dikurangi semua biaya dan pengeluaran, termasuk bunga dan pajak.

\section{Laba setelah pajak}

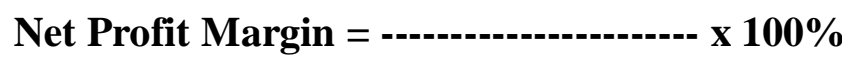 \\ Penjualan}

2. Analisis Common Size

Analisis Common Size merupakan analisis yang disusun dengan menghitung masing- masing rekening dalam laporan laba- rugi serta neraca jadi proporsi dari total penjualan( untuk laporan laba- rugi) ataupun dari total 
aktiva( untuk neraca). Data hasil analisis berguna untuk memperhitungkan tepat tidaknya kebijakan( operasi, investasi, serta pendanaa) yang diambil oleh perusahaan di masa lalu, dan mungkin pengaruhnya terhadap posisi serta kinerja keuangan perusahaan di masa yang akan datang.

3. Analisis Du Pont Merupakan analisis yang mencakup rasio kegiatan serta margin keuntungan atas penjualan untuk memastikan profitabilitas yang dimiliki perusahaan

Analisis Du Pont menyangkut kedalam rasio profitabilitas serta rasio kegiatan. Analisis du pont mempunyai kelemahan, ialah :

1). ROI suatu perusahaan susah dibandingkan dengan ROI perusahaan lain yang sejenis, sebab terdapatnya perbandingan praktek akutansi yang digunakan.

2). Dengan memakai ROI saja tidak akan dapat digunakan untukmengadakan perbandingan antara 2 kasus ataupun lebih dengan mendapatkan kesimpulan yang memuaskan.

\section{Analisis Cross Section}

Analisis laporan keuangan merupakan suatu proses riset laporan keuangan beserta unsur- unsurnya yang bertujuan untuk mengevaluasi dan memprediksi keadaan keuangan perusahaanatau badan usaha serta mengevaluasi hasilhasil yang sudah dicapai perusahaan ataupun badan usaha pada masa kemudian serta saat ini.

5. Analisis Time Series dan Forecasting Data Keuangan

Analisis time series merupakan analisis perbandingan data dengan data keuangan periode sebelumnya( perbandingan dengan data historis). Forecasting digunakan untuk memproyeksikan kondisi keuangan pada masa mendatang. Dalam analisis data keuangan, analisis terhadap data historis dibutuhkan buat melihat tren- tren yang bisa jadi timbul. Setelah itu kita dapat menganalisis apa yang terjalin dibalik tren- tren angka tersebut. Data historis perusahaan hendaknya juga dibandingkan dengan data historis industriuntuk melihat apakah tren suatu perusahaan begerak relatif lebih baik terhadap tren industri 


\section{ANALISIS DATA KEUANGAN}

Data penjualan mencerminkan 4 macam faktor:

\section{Trend}

Trend ialah pergerakan time series dalam jangka panjang, dapat merupakan tren naik atau turun. Dibutuhkan waktu jangka panjang( 15 ataupun 20 tahun) untuk melihat pola tren tersebut. Tren tersebut dapat dipengaruhi oleh perubahan jumlah penduduk, perubahan teknologi, dll

Siklus

Siklus ialah fluktuasi bisnis dalam jangka yang lebih pendek( sekitar 2- 10 tahun). Belum terdapat penjelasan yang memuaskan terhadap munculnya fluktuasi siklus. Lamanya serta besarnya fluktuasi pula sangat bermacam- macam dari perusahaan ke perusahaan serta dari industri ke industri.

$>$ Musiman

Musiman ialah fluktuasi yang terjadi dalam lingkup satu tahun. Terdapat beberapa penyebab timbulnya fluktuasi musiman, misalnya karena kejadian tertentu( lebaran, tahun baru), karena cuaca( musim hujan, kemarau).

Ketidakteraturan( Irregularities)

Fluktuasi semacam ini diakibatkan karena faktor- faktor yang timbulnya tidak teratur, dalam jangka waktu pendek. Misalnya gudang perusahaan terbakar, dampaknya keuntungan perusahaan pada periode itu terpengaruh. 


\section{BAB III}

\section{PENUTUP}

\section{A. Kesimpulan}

Analisis laporan keuangan merupakan suatu proses penelitian laporan keuangan beserta unsur-unsurnya yang bertujuan untuk mengevaluasi dan memprediksi kondisi keuangan perusahaan atau badan usaha dan mengevaluasi hasil-hasil yang telah dicapai perusahaan atau badan usaha pada masa lalu dan sekarang.Analisis laporan keuangan memiliki berbagai macam metode, yaitu:

- Analisis Rasio

- Analisis Common Size

- Analisis Du Pont

- Analisis Cross Section

- Analisis Time Series dan Forecasting Data Keuangan

\section{B. Saran}

Kami sangat berharap makalah ini dapat berguna dalam rangka menambah wawasan serta pengetahuan kita sebagai penulis maupun pembaca, sebagai penulis mengharapakan kritik dan saran yang membangun untuk menyempurnakan makalah ini untuk menjadi lebih baik lagi. 


\section{DAFTAR PUSTAKA}

Darminto, D. P. (2011). Analisis Laporan Keuangan. Yogyakarta: UPP STIM YKPN.

Harahap, S. S. (2011). Analisis Kritis atas Laporan Keuangan. Jakarta: Raja Grafindo Persada.

Maith, H. A. (2013). Analisis Laporan Keuangan Dalam Mengukur Kinerja Keuangan Pada PT Hanjaya Mandala Sampoerna Tbk. Jurnal EMBA, 1(3), 619 - 628.

Melissa Olivia Tanor, H. S. (2015). Analisis Laporan Keuangan Dalam Mengukur Kinerja Keuangan Pada PT. Bank Artha Graha Internasional, Tbk. Jurnal EMBA, 3(3), 639 $-649$.

Prihadi, T. (2019). Analisis Laporan Keuangan. Jakarta: PT Gramedia Pustaka Utama.

Wahyudiono, B. (2014). Mudah Membaca Laporan Keuangan. Jakarta: Raih Asa Sukses.

https://www.scribd.com/document/391837260/Makalah-Analisis-Laporan-

Keuangan Diakses pada tanggal 27 Desember 2021 